\title{
MULTINOMINAL BIOINDICATION FOR THE EVALUATION OF URBAN ENVIRONMENT CONDITION - CASE STUDY OF THE CITY OF KHERSON
}

\begin{abstract}
The urban environment is one of the most complicated man made systems, which condition and status are hard to define, but it is essential for the survival of humans. Among the methods of the urban environment condition evaluation bioindication is one of the most simple and able to provide valuable dose-response information for efficient management of environmental safety. Being such a useful method, the bioindication has a range of disadvantages, due to dependence on single species response, which can lie within the acceptable amplitude of living fluctuations or is conditioned by factors other than human activity. Most of the researches of such type stick to one single species and attempt to build clear impact-response dependencies for specific conditions. The paper considers the possibility to combine bioindicators from different taxonomic groups in one study to receive more reliable vision of the environment status. The typical combination offered in the study is phytoindication and lichen indication, which relies on measuring plants morphological parameters and lichen diversity and distribution. The research was conducted in the city of Kherson, previously considered relatively unpolluted. The territory of the city was analyzed to define the most affecting sources of environment pollution. The background area was chosen to verify the changes in the parameters of bioindicators. The results showed that the level of anthropogenic pressure within the urban territory is considerable and demands mitigation actions, aimed at improvement of air pollution control, waste management, traffic organization and implementation of remediation activities at decommissioned facilities. The deviations between the results of lichen indication and phytoindication gave possibility to infer the possible sources and composition of pollution, thus providing basis for efficient environment protection solutions to be implemented. The paper also presents the recommendations on the combination of bioindicators to be used in various studies, depending on the purpose and type of the ecosystem under investigation. The sequence of the data processing must include the comparative analysis of the information obtained to use the differences between the results provided by different organisms for clarification of the human impacts parameters.
\end{abstract}

Keywords: anthropogenic pressure; environment pollution; indicator organisms.

\section{Introduction}

The modern city can be compared with a single complex organism, which actively exchanges matter and energy with the surrounding natural complexes and other settlements [3]. However, unlike real organisms, they lack elements of self-regulation. Thus, any overpressure from human activity must be balanced and mitigated by the special measures undertaken by the urban population. The misbalance in the urban ecosystem is mirrored in the gradual degradation of environment quality and, in turn, health disorders of its residents. Since all living organisms as well as the ecosystems, containing natural objects, demonstrate certain level of inertia and resilience [16], it is often hard to start mitigation activities in the right time. As a result, there is a need to find the signs of urban ecosystem deterioration, which would be easily traceable and reliable in terms of potential risk assessment for human population. The most suitable and widely used techniques of this kind are bioindication methods.

\section{Analysis of the previous research}

Bioindication has been a popular environment analysis technique since the second half of the XX century. Its major advantages, namely simplicity and ability to predict human organism reactions to environment factors has made it widely used around the world and now it is even included into numerous state guidelines on environment quality control and some international control recommendations. Moreover, the study of aquatic microbiota condition is a compulsory element of water quality control in all the US [3]. certain groups of environment pollutants have been well studied in terms of defining special bioindicators for their monitoring on a global scale, as it is the case of POPs [15]. One can find a great variety of research works on bioindicator evaluation of environment quality in Ukraine and other countries. Among them the content and effects of heavy metals (Saet et al., 1985; Nikodemus et al., 1988; Moskalenko, Smirnova, 1989; Tyutyunnik, 1994; Kasimov, 1995;

Інформація про авторів:

Радомська Маргарита Мирославівна, канд. техн. наук, доцент, кафедра екології. Email: m.m.radomskaya@gmail.com; https://orcid.org/0000-0002-8096-0313

Гусєва Аліна Віталіївна, студент, кафедра екологіï. Email: waydele99@gmail.com; https://orcid.org/0000-0001-7638-3691

Горобцов Інокентій Владиславович, аспірант, кафедра екологіï. Email: inimyo7@gmail.com; https://orcid.org/0000-0001-6890-4370

Цитування за Дсту: Радомська М. М., Гусєва А. В., Горобцов І. В. Multinominal bioindication for the evaluation of urban environment condition - case study of the city of Kherson. Науковий вісник НЛТУ України. 2020, т. 30, № 5. С. 47-52.

Citation APA: Radomska, M. M., Husieva, A. V., \& Horobtsov, I. V. (2020). Multinominal bioindication for the evaluation of urban environment condition - case study of the city of Kherson. Scientific Bulletin of UNFU, 30(5), 47-52. https://doi.org/10.36930/40300508 
Oleksyn and Braginsky, 1995; Bortnik, Chervanev, 1996; Larionova, 1999; Hasselbach et al., 2005; Hluhov, 2006; Huralchuk, 2006; Markret et al, 2006; and others) and water environment quality (Rosenberg and Resh, 1992; Levich et al., 2004, 2009, 2011; Risnik, 2012;) were most often studied. The urban environment quality was evaluated using phytoindication in the works by Loginov, 2004; Mokrov, 2005; Chesnokova, 2007; Trofimov, 2007; Maksimov, 2010; Nazarenko, Mosienko, 2019; Fedorova and Shaloumov, 2017; etc.

Most of the mentioned works demonstrate a range of demerits typical for bioindication. Among the top ones is the fact that it is impossible to measure the well-being of an ecosystem based on one species preferences, as ecological niches of all species are notable different $[4,6,8]$. Another serious obstacle is the impossibility to differentiate the natural fluctuation of species from deviations caused by anthropogenic pressure. Moreover, indicator species may be affected by negative factors of natural origin, thus complicating the process of decision making on evaluation [1]. And of course the level of impact-response interaction is often fuzzy and may put any quantitative assumptions under question [2].

Since, most of the above mentioned works are very targeted and work with specific pollutants or single species as indicators. We believe that the combination of few bioindicators of different taxonomic groups in one study is the possible way to increase the accuracy of the obtained results. The multicomponent bioindication technique was offered by Shunelko E. V., 2000, but it adheres to the use of a variety of parameters of the same group of indicators - arboreal plants [14]. In their work Parpan and Mylenka, 2010, developed the algorithm of similar system, involving plants of various ecological groups, but again they stay within the same taxonomic group [13].

Thus, these research works are rather multiparametric and there is need for further research in this field.

So, the aim of the given paper is to develop the approach to efficient multinominal bioindication to improve the reliability of the results. The offered complex will be tested on the example of the city of Kherson to verify its current environmental status, undergoing considerable fluctuations during the last decade.

Object of research is degradation of environment status under the anthropogenic pressure.

Subject of research is morphological changes in living organisms under the influence of environment pollution.

Scientific novelty: The approach to combination of bioindication methods and the sequence of results analysis is proposed. The practical application of the proposed approaches will increase the reliability of the results of the environmental assessment at urban areas and improve the efficiency of nature protecting actions planning by defining the most urgent areas for their implementation.

\section{Methods and materials}

The most common definition of bioindication as a research method is the determination of the degree of pollution of the natural environment with the help of living organisms (or natural communities) [12]. Indication of environmental conditions is carried out on the basis of assessing the changes in both the species diversity of organisms of a particular locality and their chemical composition, which reflects their inherent ability to accumulate compounds and elements coming from the environment. Unlike chemical and other analytical tests bioindication methods determine exactly the response. The biological system reacts not only to individual factors, but also to the impact of the environment as a whole, and the amplitude of fluctuations of physiological tolerance may vary with the internal state of the system - age, nutritional conditions, genetically controlled resistance [6]. This response is of extreme importance for environmental studies, due to its ability to predict the upcoming health risks for human population.

Thus, the research methods applied here are phytoindication and lichen indication, which are the most well-studied and widely applied for almost 100 years.

Prior to conduction of the research the territory under investigation must be assessed in terms of technogenic pressure distribution. The areas with clear sources of environment pollution are chosen for the following analysis, as well as relatively undisturbed areas for comparison of the obtained results.

The first method involved evaluation of leaves at the trees for the purpose of finding signs of damage and degradation. At each probe ground 10-15 trees, preferably of the same species, were chosen and as much leaves as possible were visually examined. The condition of leaves and the approximate percentage of each type of damage were evaluated using the special scale (Table 1).

Table 1. Interpretation of the phytoindication results

\begin{tabular}{|c|l|c|c|}
\hline $\begin{array}{c}\text { Po- } \\
\text { ints }\end{array}$ & \multicolumn{1}{|c|}{ Character of leaves damage } & Points & $\begin{array}{c}\text { Distribution of } \\
\text { damage, \% }\end{array}$ \\
\hline 1 & no spots, healthy, normal color & 1 & $<10$ \\
\hline 2 & with a silver coating, dull & 2 & $10-20$ \\
\hline 3 & with yellowed edges or asymmetric & 3 & $20-30$ \\
\hline 4 & $\begin{array}{l}\text { with large yellow zones or zones of a } \\
\text { different color (chlorosis) }\end{array}$ & 4 & $30-40$ \\
\hline 5 & half and more shriveled leaves & 5 & $40-50$ \\
\hline 6 & defoliation & 6 & $>50$ \\
\hline
\end{tabular}

The general assessment for each site was calculated as the sum of products of points for type of damage and points for its distribution within the study area. The obtained results were interpreted as follows:

- 6-8 - favourable condition of the ecosystem, anthropogenic load is absent;

- $9-18$ - the anthropogenic load is minimal, the state of the ecosystem is normal;

- 19-25 - continuous anthropogenic load of a non-industrial nature (transport and utilities); satisfactory condition;

- 25-32 - significant anthropogenic industrial load; condition unsatisfactory;

- 33-40 - anthropogenic load above the assimilation potential of the ecosystem, dangerous condition;

- over 40 - critical condition.

The assessment of the environment status by the condition of lichens was conducted for the same probe grounds as those chosen for phytoindication. The research procedure involved the following steps:

1) At each site, 5 trees with trunk diameters over than $25 \mathrm{~cm}$ and approximately the same height were chosen so that the age was the same. We tried to stick to one tree species. Few important issues were accounted:

- to avoid roadside trees;

- to avoid dense stands with very low illumination;

- to avoid trees that could be treated with pesticides or intensively fertilized (near the fields directly or whitewashed recently);

- to avoid very old trees with the largest number of lichens. 
2) Using the measuring tape the area of lichens, covering the trunk to the height of $150 \mathrm{~cm}$ from the ground, was measured separately for each species. The girth of each tree was measured at the height of $75 \mathrm{~cm}$. The studied area of the tree was calculated as the product of girth and $150 \mathrm{~cm}$.

3) The lichens species types and names were identified.

4) The lichens condition was studied as well. It was noted whether lichen is pale, dry, has non-uniform coloration, damaged ends, loosely attached to the trunk, etc.

The study area was the city of Kherson, as it was considered the urban area with relatively low anthropogenic pollution due to the high biodiversity and mostly agricultural specialization of the economic activity. Still, it includes a range of industrial facilities contributing contaminants to the atmospheric air. According to the results of the first half of 2019, Kherson took the seventh place in the air pollution level in Ukraine, according to the National Hydrometeorological Service. The high level of air pollution was mainly due to significant average concentrations of formaldehyde, nitrogen dioxide, phenol, hydrogen fluoride, carbon monoxide, and suspended solids.

For the purpose of the research 10 zones with clear sources of environment pollution were determined, including:

- Zone 1 - poultry farm - is considered dangerous due cadaveric poisons from decomposing slaughter waste tissues to the presence of a, which poses a huge threat to public health due to.

- Zone 2 is s a decommissioned meat factory and the highway with active traffic.

- Zone 3 was chosen because there is an electromechanical plant and it is located close to the railway.

- Zone 4 is a zone near the base of building materials, producing intensive dusting of the environment.

- Zone 5 is the agricultural machinery plant with transport infrastructure and accumulations of waste.

- Zone 6-Commercial Sea Port is possibly the area with critical pollution level.

- Zone 7 is the municipal water treatment plant.

- Zone 8 is a disabled cotton mill that left a definite imprint on the environment. Also there is heavy traffic and entertainment center.

- Zone 9 is the bridge construction facility and active traffic.

- Zone 10 is a boiler station, which uses coal.

- Zone 0 is the Old Fortress Park, which is located at the center of the city, but relatively distant from the other zones with anthropogenic pressure.

\section{Results and analysis}

According to the results we obtained during the data processing, none of the sites is in normal condition, except for the background area; water treatment plant, decommissioned cotton mill and boiler station are in satisfactory state, while the intensity of bridge construction and related traffic impacts on air condition turned to be more intensive. The most degraded areas are predictably those, where poultry farm and Sea commercial port are located (Table 2).

The lichens condition and abundance were evaluated in parallel to arboreal plants condition a trees proximal to the enterprises under investigation.

Table 2. Evaluation of environment condition by phytoindication method

\begin{tabular}{|l|c|l|}
\hline \multicolumn{1}{|c|}{ Zone } & $\begin{array}{c}\text { Evalua- } \\
\text { tion }\end{array}$ & \multicolumn{1}{|c|}{ Condition } \\
\hline Zone 1. Poultry farm & 48 & Critical condition \\
\hline $\begin{array}{l}\text { Zone 2. Meat Factory (decommis- } \\
\text { sioned) }\end{array}$ & 36 & Dangerous condition \\
\hline Zone 3. Electromechanical Plant & 34 & Dangerous condition \\
\hline Zone 4. Base of building materials & 26 & $\begin{array}{l}\text { Unsatisfactory con- } \\
\text { dition }\end{array}$ \\
\hline Zone 5. Combined plant & 35 & Dangerous condition \\
\hline Zone 6. Sea commercial port & 50 & Critical condition \\
\hline Zone 7. Water treatment plant & 22 & $\begin{array}{l}\text { Satisfactory conditi- } \\
\text { on }\end{array}$ \\
\hline $\begin{array}{l}\text { Zone 8. Cotton Mill (decommissi- } \\
\text { oned) }\end{array}$ & 25 & $\begin{array}{l}\text { Satisfactory conditi- } \\
\text { on }\end{array}$ \\
\hline Zone 9. Bridge construction & 34 & Dangerous condition \\
\hline Zone 10. Boiler station & 22 & $\begin{array}{l}\text { Satisfactory conditi- } \\
\text { on }\end{array}$ \\
\hline Zone 0. Old Fortress Park & 11 & Normal condition \\
\hline
\end{tabular}

If the degree of lichen coverage of trees is analysed, then the atmospheric air condition can be considered satisfactory (Table 3). However, it is seen that some areas dangerous by phytoindication method are in satisfactory condition, when it comes to lichen indication results. And in such situation it is important to analyze the other parameter number and type of species. In our case we see that well developed lichen associations in the vicinity of poultry farm are made of nitrogen-loving species.

Table 3. Evaluation of environment condition by lichen indication method

\begin{tabular}{|l|c|c|l|}
\hline \multicolumn{1}{|c|}{ Zone } & $\begin{array}{l}\text { The relative covera- } \\
\text { ge with lichens (\%) }\end{array}$ & $\begin{array}{c}\text { Number of } \\
\text { species }\end{array}$ & \multicolumn{1}{|c|}{ General condition of the zone } \\
\hline Poultry farm & 68.3 & 4 & The lichens are in good condition, but the species are nitrogen-loving. \\
\hline $\begin{array}{l}\text { Meat processing plant (de- } \\
\text { commissioned) }\end{array}$ & 80.8 & 3 & $\begin{array}{l}\text { The lichens are dried and dusted; the species present are intermediate and } \\
\text { one is nitrogen-loving. }\end{array}$ \\
\hline Electromechanical plant & 87 & 5 & $\begin{array}{l}\text { The population is diverse and in normal condition, but is made of interme- } \\
\text { diate species. }\end{array}$ \\
\hline Base of building materials & 70.6 & 4 & The lichens are dried and dusted. \\
\hline Combined plant & 19.6 & 4 & $\begin{array}{l}\text { The lichen cover of the trees is almost absent. The condition is unsatisfac- } \\
\text { tory. }\end{array}$ \\
\hline Sea commercial port & 90.8 & 3 & The lichen cover is very dense, but dusted. \\
\hline Water treatment plant & 43.6 & 3 & $\begin{array}{l}\text { It is difficult to determine the condition due to lack of sunlight in the study } \\
\text { area. }\end{array}$ \\
\hline $\begin{array}{l}\text { Cotton plant (decommissi- } \\
\text { oned) }\end{array}$ & 56 & 3 & Some of the lichens are damaged, but still quite abundant. \\
\hline Bridge construction & 46 & 2 & $\begin{array}{l}\text { Lichens are in poor condition due to dusting and potential pollution. The } \\
\text { present species are pollution tolerant. }\end{array}$ \\
\hline Boiler station & 32 & 3 & $\begin{array}{l}\text { The lichen population is small and represented with the most resistant spe- } \\
\text { cies. }\end{array}$ \\
\hline Old Fortress Park & 90.3 & 6 & The population is diverse and in normal condition \\
\hline
\end{tabular}

The best condition of lichens is set in the vicinity of decommissioned electromechanical plant, while the phytoindication resulted in dangerous condition. This is probably due to residual pollution of soils, which affect arboreal plants, but not lichens. The trees at the sea port territory are also well covered with lichens, but the diversity is low and 
they are much dusted. Dusting of lichens is also typical for those zones, where traffic and construction are the most important source of pollution. In these points lichens are gradually drying due to increasing transport flow over the last years. They are still present in considerable quantity due to the inertia of reaction. Decommissioned facilities are well provided with lichens, and that is a global trend: studies prove that lichens come back after reduction of anthropogenic pressure [14]. The lowest area of lichen cover was defined at the zone of boiler plant, but this is due to lack of aged arboreal plants.

\section{Discussion of the results obtained}

To integrate the obtained data, the results of studies using phytoindication and lichen indication methods were summed (Table 4) to determine the areas which raise the highest environmental concerns. In those cases, when there was difference between the grades of environment condition set by the each method, the worst type was chosen, if the gradation is different by one level; and the middle grade was chosen between the evaluation results different by two and more grades. As a result, we can conclude that neither good nor satisfactory environment condition is typical for the city. The points with the critical level of pollution are unevenly distributed. The obtained results were placed on the city map and the areas with the highest anthropogenic pressure turned to be the north-east, encompassing Combined plant and Base of building materials up to the Bridge construction, while the rest of the city center is under moderate anthropogenic load (Figure). The Sea port and the south-western part of the city with are also loaded and seems to be able to impose health risks to the residents.

Table 4. Integrated evaluation of environment condition

\begin{tabular}{|l|c|c|c|}
\hline \multicolumn{1}{|c|}{ Zone } & Phytoindication results & Lichen indication results & General condition \\
\hline Zone 1. Poultry farm & Critical condition & Satisfactory & Dangerous \\
\hline Zone 2. Meat Factory (decommissioned) & Dangerous condition & Satisfactory & Unsatisfactory \\
\hline Zone 3. Electromechanical Plant & Dangerous condition & Satisfactory & Unsatisfactory \\
\hline Zone 4. Base of building materials & Unsatisfactory condition & Unsatisfactory & Unsatisfactory \\
\hline Zone 5. Combined plant & Dangerous condition & Critical & Critical \\
\hline Zone 6. Sea commercial port & Critical condition & Satisfactory & Unsatisfactory \\
\hline Zone 7. Water treatment plant & Satisfactory condition & Unsatisfactory & Unsatisfactory \\
\hline Zone 8. Cotton Mill (decommissioned) & Satisfactory condition & Unsatisfactory & Unsatisfactory \\
\hline Zone 9. Bridge construction & Dangerous condition & Critical & Critical \\
\hline Zone 10. Boiler station & Satisfactory condition & Unsatisfactory & Unsatisfactory \\
\hline Zone 0. Old Fortress Park & Normal & Normal & Normal \\
\hline
\end{tabular}

Both phytoindication and lichen indication demonstrate that the city experience noticeable anthropogenic pressure and demand a complex of mitigation activities. In particular there is a need to evaluate the current status of environment components in the impact area of decommissioned industrial facilities and plan the remediation of these territories. Such zones as poultry farm and the sea port must undergo more frequent environmental control and the plan of the pollution control equipment modernization and waste management improvement must be developed and implemented. The most typical source of air pollution is transport, which needs improvement of traffic organization and road cover quality.

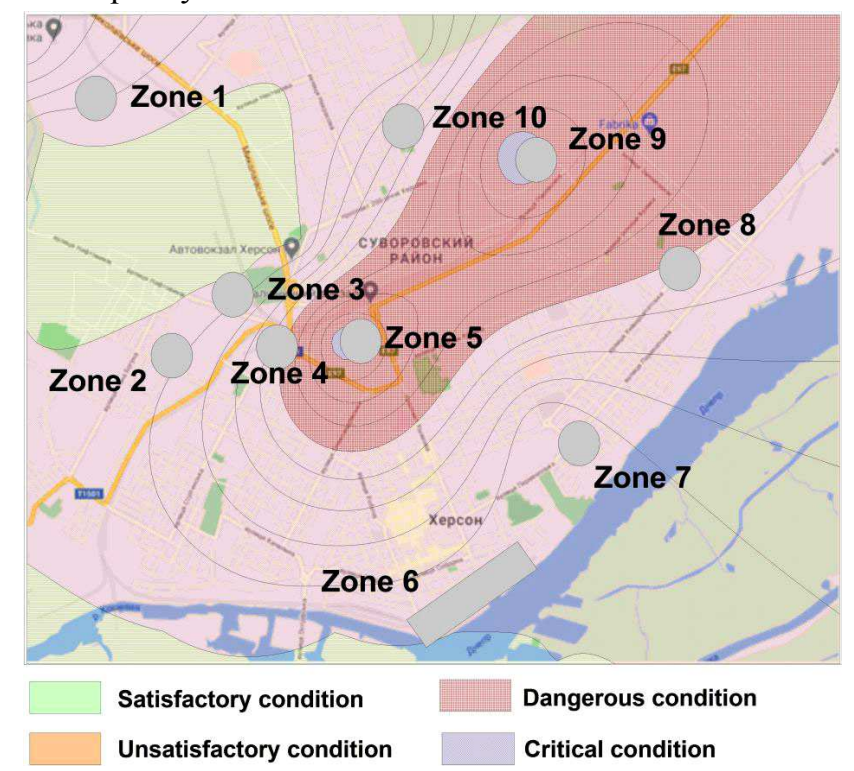

Figure. The environment condition at the city of Kherson, defined by combined bioindication method
Aggregating the research results, it is necessary to note that the proposed binominal technique of bioindication is more efficient, as compared with traditional single species methods. It is seen from the results that the phytoindication results are sometimes contradicting the lichen indication results. Thus, the processing of results must involve comparative analysis and finding explanations to possible deviations. This is the most valuable part of the work, as it gives few important outcomes: clarification of the possible composition of contaminants and the source of living organisms exposure - airborne or soil/groundwater borne. This is especially important, as the vagueness of results is inherent for the bioindication $[4,6,12]$.

Thus, the given research demonstrated that there are considerable mismatches between the results obtained by phytoindication and lichen indication. Moreover, it is not even possible to set any regularity in these mismatches, because both lichens and arboreal plants can give better and worse grades. Thus, we believe that this is the reflection of dominant pathway of organisms exposure to anthropogenic pollution, in other words, lichens typically reflect air condition, while the condition of leaves also depends on the level of plant nutrition and thus on the condition of soils and ground waters. This idea is proved by the fact that lichens gave more negative feedback in those locations where air is more intensively polluted with emissions (especially sulphur dioxide from fuel combustion) and dust of various composition. In case of the sea port good aeration is probably the reason of lichens well being.

To increase the reliability of bioindication research it is necessary to choose bioindicators of different taxonomic groups -2 or 3 depending on the tasks:

1) If the focus of work is determination of general condition of terrestrial environment, than three different taxo- 
nomic groups should be chosen, for example, lichens, macrophytes and macroinvertebrates;

2) If the focus is to differentiate the sources of pollution (the polluted component of environment and thus its potential source), than combination of embryophytes and lichens will give a good result for terrestrial ecosystems, while algae and water plants are a good combination for aquatic ecosystems, because these organism have different level of dependence on water/air/soil;

3) If the focus is to define the specific pollutants and their approximate quantity, than there should be two taxonomically different organisms sensitive to the pollutants of interest should be chosen; if the names of corresponding species are unknown, a series of tests on the arboreal plants present in the study area will give the name of the most sensitive species;

4) If the research is aimed at the study of the specific component of environment than at least 2 species of different groups or 3 species of the related groups can be chosen, for example a good result could be obtained by the combined survey or deciduous and coniferous plants or few species of aquatic microphytes and moluscs;

5) The use of organisms with different life expectancy is normally not recommended in the bioindication, but it may give valuable information about the temporal characteristics of environment pollution, as in the case of essay with the leaves of deciduous and coniferous plants and lichens, or the use of perennial and annual grasses, macroinvertebrates with different length of life cycles etc. The most important parameter in this case is the sedentary way of life. However, this approach raises concerns about the magnitude of delay between an organism reaction and moment of pollution [7].

6) The reliability of the results obtained from one bioindicator may be increased by studing few parameters morphological, chemical, biodiverse, ets. This is especially the case with lichens, whose morphological parameters, distribution, diversity, character of species (based on sensitivity to certain pollutants) and chemical composition can be used in complex to verify the evaluations.

\section{Conclusions}

The city of Kherson was previously considered relatively clean areas, but recently they have dropped to the end of the rating, for this reason our research was primarily aimed at evaluation of the general environmental situation in the city. To fulfil this task we chose the combination of bioindication method, in particular, phytoindication and lichen indication methods.

At the first stage of research the areas of the city of Kherson subjected to excessive anthropogenic stress were defined - a total of 10 areas. Our studies using phytoindication and lichen indication methods have shown that the city is subjected to considerable anthropogenic stress (the condition of the environment from satisfactory to critical) and needs a complex of actions, specific for each zone.

The accuracy of environment condition evaluation with the methods of bioindication is considerably increased if a combination of indicators of indicator parameters is used. The specific set of bioindicators depends on the purpose of the research (evaluation of general environment condition, condition of specific environment component, determination of types of pollutants and their approximate quantity, setting time and duration of pollution and exposure, etc.) and type of ecosystem (terrestrial or aquatic).

\section{References}

1. Follner, K., Hofacker, A., Glaeser, J., Dziock, F., Gerisch, M., Foeckler, F., Ilg, Ch., Schanowski, A., Scholz, M., \& Henle, K. (2010). Accurate environmental bioindication in floodplains in spite of an extreme flood event. River Research and Applications, 26, 877-886. https://doi.org/10.1002/rra. 1300

2. Geissen, V., \& Kampichler, C. (2004). Limits to the bioindication potential of Collembola in environmental impact analysis: A case study of forest soil-liming and fertilization. Biology and Fertility of Soils, 39, 383-390. https://doi.org/10.1007/s00374-003-0714-2

3. Golubiewski, N. (2012). Is there a metabolism of an urban ecosystem? An ecological critique. Ambio, 41(7), 751-764. https://doi.org/10.1007/s13280-011-0232-7

4. Hodkinson, I., \& Jackson, J. (2005). Terrestrial and Aquatic Invertebrates as Bioindicators for Environmental Monitoring, with Particular Reference to Mountain Ecosystems. Environmental management, 35, 649-666. https://doi.org/10.1007/s00267-004$\underline{0211-\mathrm{x}}$

5. Kusnetsov, V. V., Rakitin, V. Yu., \& Borisova, N. N. (1993). Why does heat shock increase salt resistance in cotton? Plant. Physiol. Biochem, 31, 181-188.

6. Markert, B. Breure, A., \& Zechmeister, H. (2003). Definitions, strategies and principles for bioindication/biomonitoring of the environment. Trace Metals and other Contaminants in the Environment, 6, 3-39. https://doi.org/10.1016/S0927-5215(03)80131-5

7. Markert, B., Wappelhorst, O., \& Weckert, V. (1999). The use of bioindicators for monitoring the heavy-metal status of the environment. $J$ Radioanal Nucl Chem, 240, 425-429. https://doi.org/10.1007/BF02349387

8. Miller, S. W., Wooster, D., \& Li, J. (2007). Resistance and resilience of macroinvertebrates to irrigation water withdrawals. Freshwater Biology, 52, 2494-2510. https://doi.org/10.1111/j.1365-2427.2007.01850.x

9. Motyka, O., Pavlikova, I., Bitta, J., \& Frontasyeva, M. (2020). Moss biomonitoring and air pollution modelling on a regional scale: delayed reflection of industrial pollution in moss in a heavily polluted region? Environmental Science and Pollution Research, https://doi.org/10.1007/s11356-020-09466-w

10. Paleg, L., Stevart, G. R., \& Bradbeer, J. W. (1994). Proline and glicine betaine in fluences protein salvation. Plant Physiol, 75, 974-978.

11. Parpan, V. I., \& Mylen'ka, M. M. (2009). Contents of free proline of arboreal plants as indication sign of ecological state urbanized territories. Proc. of the State Nat. Hist. Museum, 25, 155-160.

12. Parpan, V. I., \& Mylenka, M. M. (2010). Methodological aspects of the evaluation of ecological conditions of urbanized and anthropologically altered territories. Visnyk of Dnipropetrovsk University, Biology. Ecology, 18(2), 61-68. [In Ukrainian].

13. Shunelko, E. V. (2000). Mnogokomponentnaia bioindikatciia gorodskikh transportno-selitebnykh landshaftov. Abstract of Candidate Dissertation for Biology Sciences (03.00.16 Ecology). Voronezh State University, $20 \mathrm{p}$.

14. Shunelko, E. V. (2010). Multicomponent bioindication of urban transport and residential landscapes. Abstract of Candidate Dissertation for Biology Sciences (03.00.16 - Ecology). Voronezh State University, 22 p. [In Russian].

15. Tanabe, S., \& Subramanian, A. (2006). Bioindicators of POPs: Monitoring in Developing Countries. Kyoto, Japan: Kyoto University Press, $260 \mathrm{p}$.

16. Westman, W. E. (1978). Measuring the Inertia and Resilience of Ecosystems. BioScience, 28(11), 705-710. https://doi.org/10.2307/1307321

17. Zander, R., \& Showman, R. E. (1981). Lichen Recovery Follows Air Quality Improvement. BioScience, 31(11), 840-841. https://doi.org/10.2307/1308683 


\section{ПОЛІНОМІНАЛЬНА БІОІНДИКАЦІЯ ДЛЯ ОЦІНЮВАННЯ СТАНУ МІСЬКОГО ДОВКІЛЛЯ НА ПРИКЛАДІ МІСТА ХЕРСОН}

Розглянуто підходи до аналізу стану навколишнього середовища біологічними методами, що дають змогу підвищити інформативність та достовірність отриманих результатів. Показано, що біоіндикація, як метод дослідження частково змінених екосистем, що $є$ типовими для міського середовища, дає значний обсяг інформації та $є$ достатньою для виявлення чітких залежностей між інтенсивністю впливу та змінами, що відбуваються у біологічних системах унаслідок цього. Водночас, відзначено, що біоіндикація має низку недоліків, зумовлених залежністю від реакції одного виду, яка може лежати в межах прийнятної амплітуди коливань параметрів життєдіяльності, або бути зумовлена факторами іншими, ніж діяльність людини. У цій роботі розглянуто можливість поєднання біоіндикаторів з різних таксономічних груп в одному дослідженні для отримання більш достовірної відповіді про стан довкілля. Типовою комбінацією, запропонованою у дослідженні, $є$ фітоіндикація та ліхеноіндикація, що спираються на вимірювання морфологічних параметрів рослин та різноманітності та поширення лишайників. Для дослідження було обрано місто Херсон, що раніше вважалося відносно незабрудненим. Територію міста проаналізовано для визначення найвагоміших джерел забруднення навколишнього середовища. Фонову зону обрано для перевірки змін параметрів біоіндикаторів. Результати показали, що рівень антропогенного тиску в межах міської території є істотним і потребує пом'якшувальних заходів, спрямованих на вдосконалення контролю забруднення атмосферного повітря, управління відходами, організацію транспортного руху та здійснення заходів з рекультивації на об'єктах, що виводяться 3 експлуатації. Встановлено, що відхилення між даними ліхеноіндикації та фітоіндикації дає змогу визначити можливі джерела та склад забруднення і цим самим забезпечити основу для прийняття ефективних рішень для охорони довкілля. Надано також рекомендації щодо комбінації біоіндикаторів, які варто використовувати в різних дослідженнях, залежно від призначення та типу досліджуваної екосистеми. Запропоновано включити у послідовність оброблення даних порівняльний аналіз результатів, отриманих від різних біоіндикаторів, для уточнення параметрів впливу людини на довкілля.

Ключові слова: антропогенне навантаження; забруднення довкілля; організми-індикатори. 